9 - ORIGINAL ARTICLE EXPERIMENTAL ORTHOPAEDIC SURGERY

\title{
Effective reinnervation of the quadriceps femoris by spinal ventral root cross-anastomosis in rats $^{1}$
}

\author{
Reinervação efetiva do quadríceps femoral pela anastomose cruzada via raiz espinhal ventral \\ em ratos
}

\author{
Chao Song', Gui-bin Zhong', Zu-de Liu' ${ }^{\mathrm{III}}$, Wei Li ${ }^{\mathrm{IV}}$, Peng-wen Niv ${ }^{\mathrm{I}}$ Zhi-guang Qiao ${ }^{\mathrm{VI}}$ \\ IMD, Department of Orthopaedic Surgery, School of Medicine, Shanghai Jiao Tong University, Affiliated Renji Hospital, China. Main author, study \\ design and manuscript preparation.

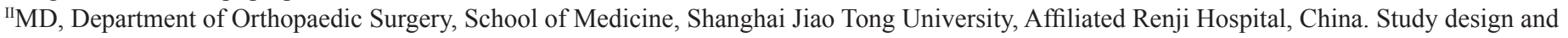 \\ critical revision. \\ IIIMD, Department of Orthopaedic Surgery, School of Medicine, Shanghai Jiao Tong University, Affiliated Renji Hospital, China. Responsible for \\ conception of the study and critical revision. \\ ${ }^{\mathrm{IV}} \mathrm{MD}$, Department of Orthopaedic Surgery, School of Medicine, Shanghai Jiao Tong University, Affiliated Renji Hospital, China. Acquisition and \\ interpretation of data. \\ ${ }^{\mathrm{v}} \mathrm{MD}$, Department of Orthopaedic Surgery, School of Medicine, Shanghai Jiao Tong University, Affiliated Renji Hospital, China. Acquisition, \\ interpretation of data and critical revision. \\ ${ }^{\mathrm{VI} M D}$, Department of Orthopaedic Surgery, School of Medicine, Shanghai Jiao Tong University, Affiliated Renji Hospital, China. Statistical analysis.
}

\begin{abstract}
PURPOSE: To study the effective recovery of the quadriceps femoris by spinal ventral root cross-anastomosis in rats.

METHODS: End-to-end anastomosis was performed between the left $\mathrm{L}_{1}$ and $\mathrm{L}_{3}$ ventral roots using autogenous nerve graft , and the right $\mathrm{L}_{1}$ and $\mathrm{L}_{3}$ roots were left intact. In control animals, the left $\mathrm{L}_{3}$ ventral root was cut and shortened, and anastomosis was not performed. Six months postoperatively, the movement of low extremities was detected by electrophysiological examination, hindlimb locomotion and basso, beattie and bresnahan (BBB) scoring at one, three, seven, 14, 21 and 28 days after SCI. Fluorescence retrograde tracing with TRUE BLUE (TB) and HE staining were performed to observe the nerve regeneration.

RESULTS: Six months after surgery, the anastomotic nerve was smooth and not atrophic. The amplitudes of action potential were $7.63 \pm 1.86 \mathrm{mV}$ and $6.0 \pm 1.92 \mathrm{mV}$ respectively before and after the spinal cord hemisection. The contraction of left quadriceps femoris was induced by a single stimulation of the anastomotic nerve. The locomotion of left hindlimb was partially restored after spinal cord hemisection while creeping and climbing. In addition, there was significant difference in the BBB score at one, three and seven days after SCI. TB retrograde tracing and neurophysiologic observation indicated efficient reinnervation of the quadriceps femoris.

CONCLUSION: The cross-anastomosis between spinal ventral root can partially reconstruct the function of quadriceps femoris following SCI and may have clinical implication for the treatment of human SCI.
\end{abstract}

Key words: Reinnervation. Quadriceps Muscle. Spinal Nerve Roots. Rats.

\section{RESUMO}

OBJETIVO: Investigar a recuperação efetiva do músculo quadríceps femoral pela anastomose cruzada via raiz espinhal ventral em ratos.

MÉTODOS: Anastomose término-terminal foi realizada entre as raízes ventrais $\mathrm{L}_{1}$ e $\mathrm{L}_{3}$ à esquerda usando enxerto autógeno de nervo e, à direita, as raízes $\mathrm{L}_{1}$ e $\mathrm{L}_{3}$ foram mantidas intactas. Nos animais controles, à esquerda, a raiz ventral de $\mathrm{L}_{3}$ foi cortada e encurtada sem realização de anastomose. Após seis meses, o movimento das extremidades posteriores foi estudado por exame eletrofisiológico, e pelo escore de basso, beattie e bresnahan (BBB) com um, três, sete, 14, 21 e 28 dias após SCI. Fluorescência retrograde feita com TRUE BLUE (TB) e coloração com HE foram realizadas para observar a regeneração do nervo.

RESULTADOS: Seis meses após a cirurgia, a anastomose do nervo estava lisa e sem atrofia. As amplitudes dos potenciais de ação

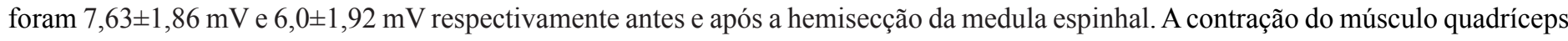
femoral foi induzida por um único estímulo do nervo anastomosado. A locomoção do membro posterior esquerdo foi parcialmente restaurada após hemisecção da medula espinhal ao rastejar e escalar. Ademais, houve diferença significante no escore BBB nos dias um, três e sete após SCI. O traçado da TB retrógrada e a observação neurofisiológica indicaram reinervação eficiente do quadríceps femoral. CONCLUSÃO: A anastomose cruzada entre as raízes espinhais ventrais podem reconstruir parcialmente a função do quadríceps femoral após SCI e pode ter implicação clínica para o tratamento da SCI.

Descritores: Reinervação. Músculo Quadríceps. Raízes Nervosas Espinhais. Ratos. 


\section{Introduction}

To reconstruct the motor and sensory function of paralytic extremity after spinal cord injury (SCI) remains a major challenge. Nerve transfer or neurotization has been commonly described to treat the spinal cord injury in animal model or clinical patients. There are a number of studies that have demonstrated the regenerative capacity after various injuries to ventral roots. As early as 1969, Thulin ${ }^{1}$ began to study on reconstruction of ventral roots ${ }^{2}$. But only rewiring the nerve roots did not prove that axons regenerated successfully. So from 1980 on, Richardson and Aguayo $^{4}$ started a series of studies on outgrowth of motor axons from the CNS to motor nerves ${ }^{3,5}$. The experimental studies in adult rodents indicate that neurons in spinal cord are capable of extensive axonal growth along peripheral nerve grafts inserted into the CNS. Decherchi et al. ${ }^{6,7}$ found that supra-lesional posttraumatic nerve grafts may induce axonal regrowth of chronically axotomized adult central neurons, but time need delayed. Carlstedt et al. ${ }^{8}$ founded a model for axon regeneration in the central nervous system by cut lesion in the ventral part of the spinal cord. The experiments suggested that replantation of avulsed spinal ventral roots had been shown to enable significant and useful regrowth of motor axons in both experimental animals and in human clinical cases $^{9-15}$.

In recent years, Havton et al. ${ }^{16,17}$ implanted of avulsed lumbosacral ventral roots into the spinal cord and the result showed it could promote reinnervation of the urinary tract and return of functional micturition reflexes. Based on these studies above, many researchers and scholars began to study how to restore the motor function of limbs after SCI. Malik et al. ${ }^{18}$ put forward to an animal model for intercostals nerve transfer and saphenous nerve grafting to lumbar nerve roots. Further, the feasibility of intercostals nerve transfer and autogenously sural nerve grafting to the lumbar and sacral nerve roots in the adult and infant human cadaver in demonstrated. From 1978 to 1985, 10 intercostal nerve-cauda equina anastomoses and 11 intercostal nerve-lumbar anastomoses were performed by for thoracolumbar spinal cord transection. Three to four pairs of intercostal nerves above the traumatic level of the cord were anastomosed with two to four pairs of cauda equina or lumbar nerve roots below the traumatic level, using microsurgical technique. The results showed that intercostal-lumbar-spinal nerve anastomoses provide a chance for neuronal regeneration, but unsatisfactory functional results are still questions for further study ${ }^{19}$. Tok et al. ${ }^{20}$ performed end-to-end anastomoses between the motor roots of T12 and T13 intercostal nerves and the ipsilateral transected L1 lumbar nerve.
The clinical and electrophysiologic findings showed functional viability. Hence, researchers thought the method was practical. Vialle et al. ${ }^{21}$ proved the anatomical feasibility of using the ninth, 10 th, and $11^{\text {th }}$ intercostal nerves for the treatment of neurological deficits after damage to the spinal cord. They also demonstrated the technical feasibility of intercosto-lumbar neurotizations in a big mammalian model and from human anatomy ${ }^{22,23}$. But there were unsatisfied results with regard to restoring the hindlimb movement after $\mathrm{SCI}^{18,24,25}$. Because intercostal nerves are mixed ones and lumbar ventral nerves are motor ones, there must be crossover growth among different nerve fiber bundles. Thus, the target organs were not effectively innervated after they were anastomosed. We propose a method in which end-to-end anastomosis was performed between the spinal ventral roots of rats following SCI to reconstruct a paraspinal neural pathway for quadriceps femoris, and then electrophysiological examination was carried out to detect the recovery of hindlimb movement. To test this conception, we designed the experiment on the SpragueDawley rats.

\section{Methods}

Twenty male Sprague-Dawley (SD) rats weighing 120 150g were purchased from the Experiment Animal Centre of Chinese Academy of Sciences. Animals were handled according to the guide for the care and use of laboratory animals, guidelines for the use of animals in neuroscience research, and China laws relating to animal experiments. Ten rats belonged to experimental group, and the others served as control group.

\section{Surgical procedure}

Rats were anaesthetized with $1 \%$ pentobarbital sodium intraperitoneally $(1 \mathrm{ml} / 100 \mathrm{~g})$ and placed in a prone position on an operating table. Under the aseptic condition, a posterior middle incision was made in the back from L1 to L5 to expose the vertebrae. The $13^{\text {th }}$ ribs are the most caudal pair and also known floating ribs under which the T13 intercostal nerve can be identified. Along the intercostal nerve, its origin was exposed, and the $\mathrm{T}_{13}$ spinal nerve and its ventral and dorsal roots were also isolated. Then, the $\mathrm{L}_{1}-\mathrm{L}_{5}$ spinal nerves were seperated from surrounding tissues one by one. A left hemilaminectomy was performed between $\mathrm{L}_{1}$ and $\mathrm{L}_{5}$ and the dura mater and spinal cord were exposed. With the aid of a surgical microscope, the ganglion in the intervertebral foramen and the ventral and dorsal roots of proximal spinal nerve were separated. The electromyograms of quadriceps femoris were recorded following the stimulation of 
ventral roots of spinal nerves $\left(\mathrm{L}_{1}-\mathrm{L}_{5}\right)$. The maximal amplitudes of action potential were recorded respectively: $0.28 \pm 0.09 \mathrm{mv}$ in $\mathrm{L}_{1}, 1.48 \pm 0.32 \mathrm{mv}$ in $\mathrm{L}_{2}, 15.87 \pm 1.16 \mathrm{mv}$ in $\mathrm{L}_{3}, 14.24 \pm 0.51 \mathrm{mv}$ in $\mathrm{L}_{4}$ and $1.07 \pm 0.39 \mathrm{mv}$ in $\mathrm{L}_{5}$. Therefore, the result showed that $\mathrm{L} 3$ spinal ventral root mostly innervates the quadriceps femoris, and $\mathrm{L}_{1}$ spinal ventral root has little effect. Then, the $\mathrm{L}_{1}$ ventral root was transected at the site close to the ganglion, the $\mathrm{L}_{3}$ ventral root transected at the site far from the ganglion but the dorsal roots were left intact. Under a surgical microscope $(10 \times)$, the proximal end of $\mathrm{L}_{1}$ ventral root was anastomosed epineurially to the distal end of $\mathrm{L}_{3}$ ventral root with autologous nerve graft from cocygeal nerve using an 11.0 atraumatic needle and monofilament nylon suture (Figure 1A and B).

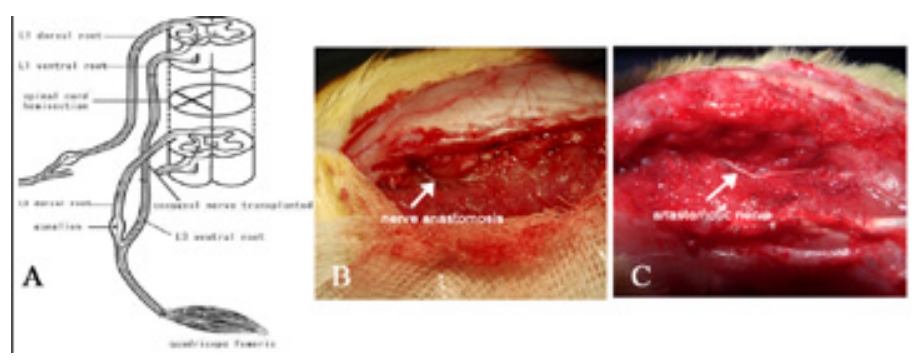

FIGURE 1 - A. Paraspinal neural pathway of quadriceps femoris. B. Anastomosis between the spinal ventral roots. C. Anastomotic nerve six months after surgery.

In control animals, the $\mathrm{L}_{3}$ ventral root was cut and shortened, but anastomosis was not performed. All rats were then housed for 6 months before the following experiments were performed.

\section{Electromyography of quadriceps femoris}

After anesthesia, the rats (six months postoperative) were placed in a prone position on the operating table and fixed. Under the aseptic condition, a lateral incision was made in the hindlimb and the quadriceps femoris exposed. The recording electrodes were put on the muscle belly and distal tendon, and the stimulating electrodes on the anastomotic nerve. Action potential of quadriceps femoris was recorded by stimulating the anastomotic nerve with a single square-wave $(2.5 \mathrm{~mA}, 0.2 \mathrm{~ms}, 1 \mathrm{HZ})$. In the same way, another action potential was recorded after spinal cord hemisection was confirmed.

\section{Electrophysiology of the anastomotic nerve}

Rats were anaesthetized, positioned and fixed in the same way above. Under the aseptic condition, the former incision was made in the back to expose the vertebrae. After the $13^{\text {th }}$ rib was identified, the $\mathrm{L}_{1}$ spinal nerve root was exposed. The anastomotic nerve close to the $\mathrm{L}_{1}$ spinal nerve root was then separated from surrounding tissues (Figure 1C).

A left hemilaminectomy was performed between $T_{12}$ and $\mathrm{T}_{13}$ and the dura mater and spinal cord were exposed. Then, the origin of $\mathrm{T}_{12}$ spinal nerve root was identified and the origin of $\mathrm{T}_{13}-\mathrm{L}_{2}$ spinal nerves also exposed in turn. The hemisection was made in the spinal cord at the level of $\mathrm{L}_{2}$ spinal nerve root. Four weeks after surgery, action potential of quadriceps femoris was recorded following the stimulation of anastomotic nerve with single square-wave $(2.5 \mathrm{~mA}, 0.2 \mathrm{~ms}, 1 \mathrm{HZ})$.

\section{Clinical assessment}

The hindlimb locomotion was observed once the hemisection of spinal cord was confirmed. Four weeks after surgery, the walking and ascending tests were performed.

Basso, beattie and bresnahan (BBB) score of rats with $S C I$

BBB scoring was performed one, three, seven, 14, 21 and 28 days after the spinal cord hemisection was confirmed. Before scoring, the bladder engorge degree was detect to avoid its influence on the movement. Two examiners blind to the study independently performed the functional assessment to hindlimb movement.

\section{Preparation for microscopy}

The nerve specimen were taken from the anastomotic nerve, and embedded in paraffin. Then the specimen were cut into $40 \mu \mathrm{m}$ sections and stained with haematoxylin and eosin followed by observation of axon regeneration with Leica Fw 4000 image Analysis System (Leica, Solms, Germany). Meanwhile another anastomotic nerve (about $5 \mathrm{~mm}$ in length) was taken and fixed in $2.5 \%$ glutaraldehyde and $1 \%$ osmic acid followed by transmission electron microscopy. The nerve specimen of control group and the contral normal L3 ventral root were performed in the same way for microscopy.

\section{TB fluorescent retrograde tracing}

Once the spinal cord hemisection was confirmed, the affected femoral nerve was separated from surrounding tissues four weeks after surgery. Then $40 \mu \mathrm{l}$ of TB were slowly injected with a microsyringe into the affected femoral nerve and the syringe remained at the injection site for $1 \mathrm{~min}$. One week later, an incision was then made in the chest and the heart was exposed under anesthesia. A syringe was inserted into the left ventricle and then into the ascending aorta. Then, $50 \sim 300 \mathrm{ml}$ of normal 
saline were injected quickly to flush the vessels. Within $5 \mathrm{~min}, 1 \%$ metaformaldehyde and $1.25 \%$ glutaraldehyde in $500 \mathrm{ml}$ of $0.1 \%$ phosphate buffer at room temperature was injected into the vessel. The half of volume was injected slowly and the remaining half injected quickly. Irrigation was finished within half an hour when a laminectomy was performed from the $\mathrm{T} 11$ to $\mathrm{S} 1$ to expose the spinal cord of T13 L4 which were then removed and embedded in the fixing fluid mentioned above. Four to six hours later, these segments were immersed in $0.2 \mathrm{~mol} / \mathrm{L} 10 \%$ phosphate buffer and saccharin fluid at $4^{\circ} \mathrm{C}$ overnight. Then, the tissues were frozen and cut into $40-\mu \mathrm{m}$ sections which were enmeshed in $0.1 \mathrm{~mol} / \mathrm{L}$ phosphate buffer for $24 \mathrm{~h}$ at $4^{\circ} \mathrm{C}$. The distribution and quantity of TB positive cells were detected.

\section{Results}

\section{Electrophysiological connection}

Electrical stimulus was used to excite the anastomotic nerve, and the action potential from quadriceps femoris was recorded before and after the spinal cord hemisection. Compared with the wave form before paraplegia, the shape and amplitude of action potential was similar to those of the affected side. The amplitudes were $7.63 \pm 1.86 \mathrm{mV}$ and $6.0 \pm 1.92 \mathrm{mV}$, respectively (Figure 2A and B).
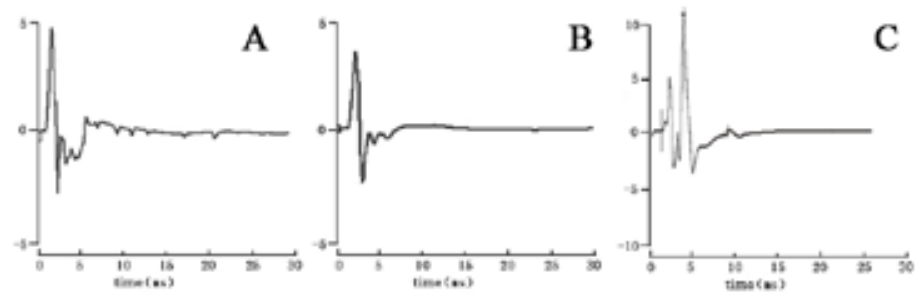

FIGURE 2 - A. Action potential of the affected side before paraplegia. B. Action potential of the affected side after paraplegia. C. Action potential of the intact side.

The amplitude of action potential following the stimulation of contralateral L3 (normal) spinal nerve root was $15.87 \pm 1.16 \mathrm{mV}$ (Figure 2C) which was higher than that of ipsilateral stimulation before and after paraplegia. In the control group, due to absence of anastomosis, lumbar ventral root atrophied and the action potential was not recorded.

\section{Motor recovery}

Motor behavior was observed and videotaped weekly. Four weeks after the spinal cord hemisection was confirmed, the rats in experimental group could walk with the affected hindlimb which was hauled on the ground accompanied by locomotion of the hip and knee (Figure 3A). In an ascending test, rats could finish the ascending action with the hip and knee testing the affected side (Figure 3B).
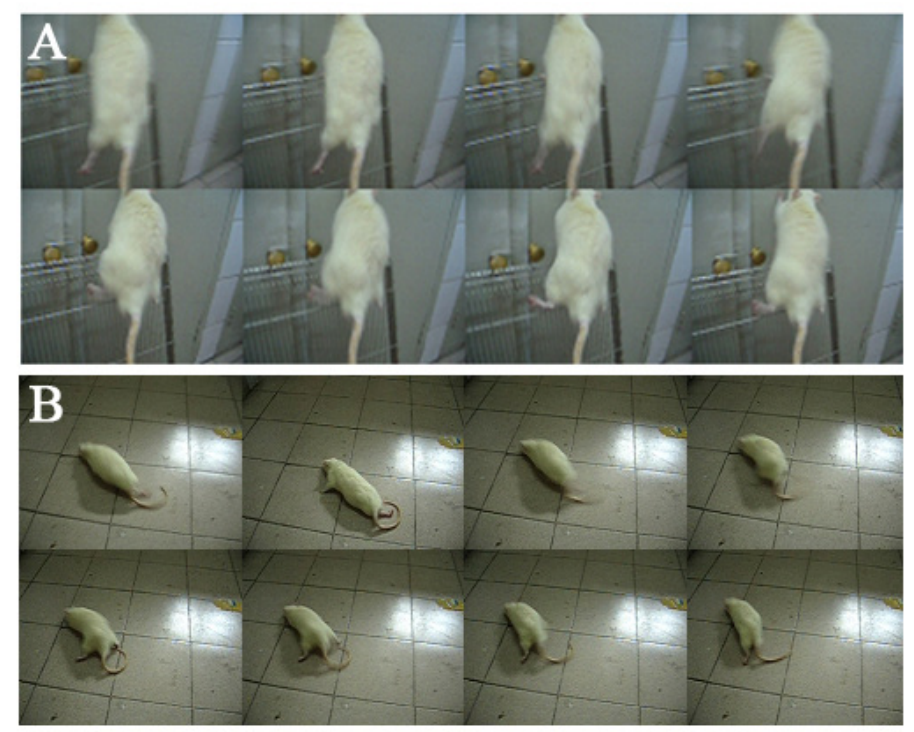

FIGURE 3 - A. Walking test after paraplegia. B. Ascending test after paraplegia.

The anastomotic nerve was successfully separated from surrounding tissues in rats with SCI and stimulated with electricity. The contraction of quadriceps femoris was observed simultaneously accompanied by the locomotion of the hip and knee in the affected side.

\section{$B B B$ score of rats following $S C I$}

The BBB score of rats before paraplegia was 21. After spinal cord hemisection, the rats had a loss of bilateral hindlimb function for a while including muscle strength deletion and bladder dysfunction, presentations of spinal cord shock. Three days later, the hindlimb function in the opposite side began to recover, and restored to normal two weeks later. The hindlimb in the affected side had little motion three days after surgery and the muscle strength started to recover gradually seven days post-operatively. The spinal cord function further recovered and was kept stable from day 14 to day 21 . There was a significant difference in the BBB score at one, three and seven days and small difference at 14, 21 and 28 days after SCI. However, the BBB score after spinal cord hemisection in control group was always 0 (Table 1, Figure 4). 
TABLE 1 - Mean BBB score of hindlimb movement after spinal cord hemisection at different time point.

\begin{tabular}{|c|c|c|c|c|c|c|}
\hline & 1day & 3day & 7day & 14day & 21day & 28day \\
\hline Control & 0 & 0 & 0 & 0 & 0 & 0 \\
\hline Experimental & 0 & $1.85 \pm 1.78$ & $5.76 \pm 2.54$ & $12.25 \pm 1.96$ & $12.86 \pm 1.55$ & $13.02 \pm 1.22$ \\
\hline Normal & 0 & $4.90 \pm 2.43$ & $15.50 \pm 1.76$ & $20.70 \pm 0.65$ & $20.80 \pm 0.67$ & $20.80 \pm 0.57$ \\
\hline
\end{tabular}

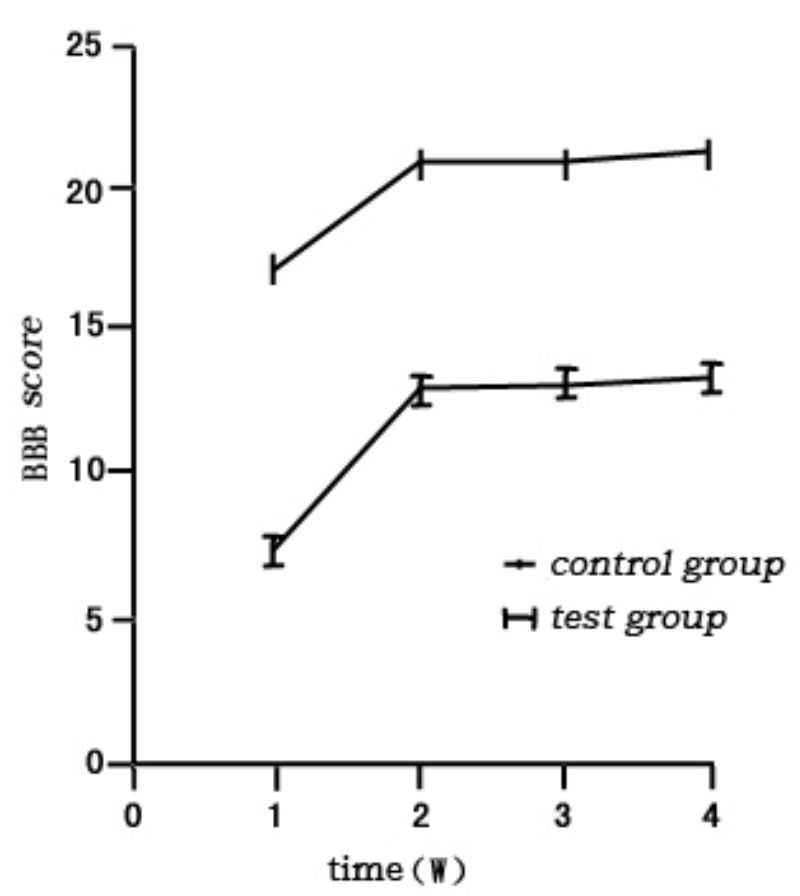

FIGURE 4 - The BBB score of test group and control group after paraplegia.

\section{Neurohistologic observation}

The anastomotic site of nerves was smooth, round, no atrophy, neuroma or scar was noted (Figure 1C). Under light microscope, HE stained that the neural fibers of L1 ventral root was found to regenerate into the anastomotic site, the longitudinal section of which showed that the nerve fibers were well arranged, and no neuroma or scar was observed. The cross-section showed that the regenerated nerve fibers presented as a typical myelinated nerve fiber structure (ie. myelin sheath in the periphery nerve and nerve axon in the center). The number of anastomosis nerve fibers on the experimental side was $959 \pm 81$, and $1021 \pm 149$ on the contral normal side respectively. There was no statistically significant difference of fiber number between the anastomosis nerve and the normal nerve $(\mathrm{P}>0.05)$ (Figure 5). The control nerve fibers were atrophic and no myelin sheath or axon was found in the crosssection observation (Figure 5C)
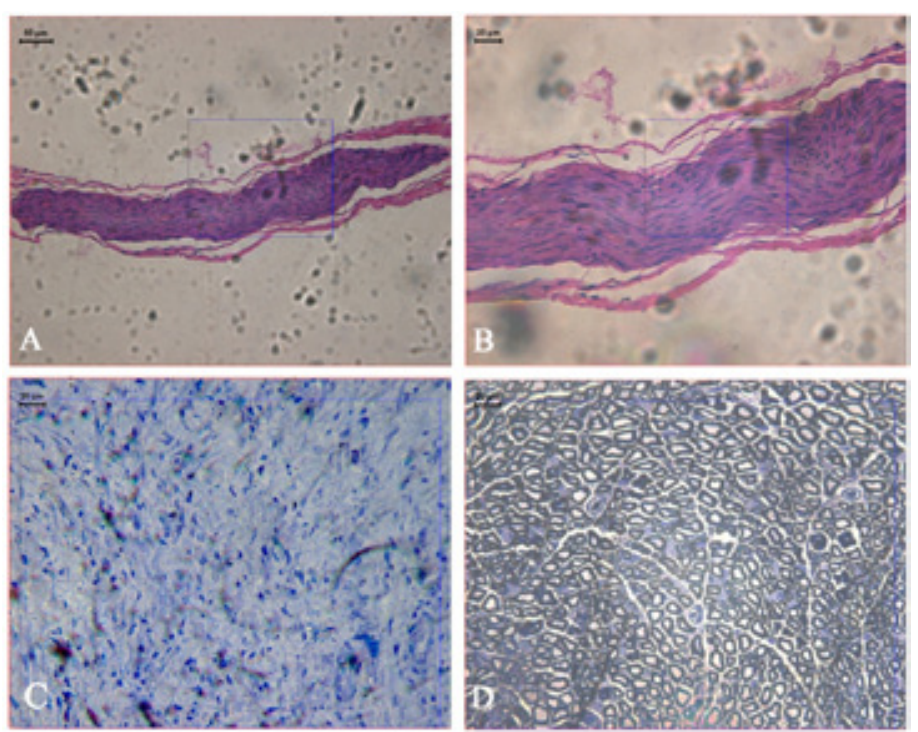

FIGURE 5-A. Axon regeneration at the anastomotic site of L1 and L3 (HE staining; magnification: $\times 20$; longitudinal section). B. Axon regeneration at the anastomotic site of L1 and L3 (HE staining; magnification: $\times 40$; longitudinal section). C. Photomicrograph of the control nerve crosssection(HE staining; magnification: $\times 40$ ). D. The anastomotic site of L1 and L3 (HE staining; magnification: $\times 40$; cross section).

\section{Ultramicrostructure of the anastomotic nerve}

Under transmission electron microscope, there were mitochondria, a lot of synaptic vesicles and myelin sheaths. The structure and conformation were similar to the normal spinal nerve (Figure 6).

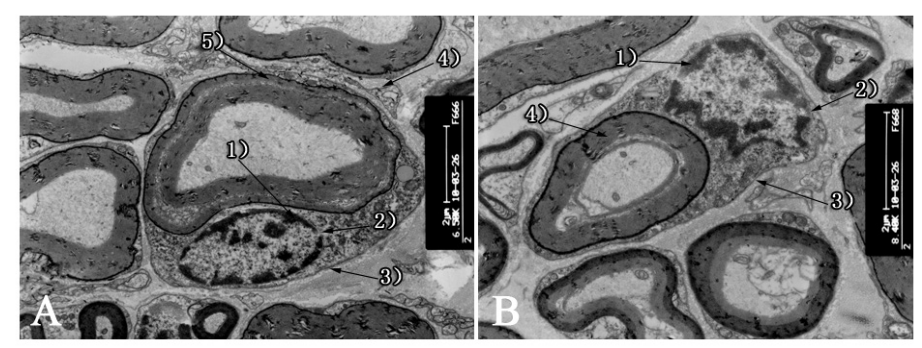

FIGURE 6 - A. Ultramicrostructure of nerves at the anastomotuc site: 1) mitochondria; 2) synaptic vesicle; 3 ) axomembrane of nerve ending; 4) collagen; 5) myelin sheath. B. Ultramicrostructure of normal nerves:

1) mitochondria; 2) synaptic vesicle; 3 ) axomembrane of nerve ending;

4) myelin sheath. 


\section{Structure and distribution of TB positive cells at L1 3}

In experimental rats, injection of $\mathrm{TB}$ into the affected femoral nerve led to labeling of motor neuron bodies. Under a light microscope, TB positive cells were found in the ventral corn of L1 in the affected side. These cells appeared dark blue and polygonous, and had some enations which arranged in groups. Computer image system analysis showed the mean cell area was $258 \pm 108 \mathrm{um}^{2}$, diameter was $7.8 \pm 1.5 \mathrm{um}$, which are similar to value for a motor neurons. The mean total number of labeled motor neurons was $289 \pm 68$. TB positive cells in the control group were negative (Figure 7).
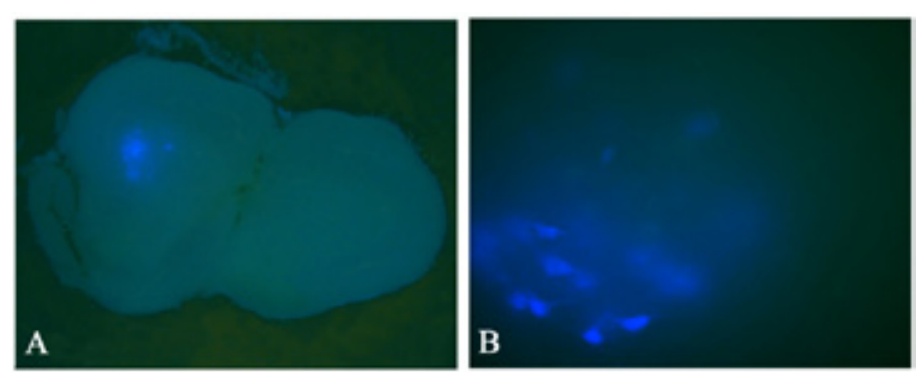

FIGURE 7 - TB positive cells (A: 40x; B: 100x).

\section{Discussion}

SCI can result in severe dysfunction of somatic motor and sensation. The mortality of SCI patients in US is estimated to be 32 per million annually, the prevalence of SCI is 906 per million annually. In addition, $85 \%$ of the injury is above the conus medullaris ${ }^{26}$. Therefore, to develop an effective strategy is extremely important both clinically and socially, which can improve the quality of life of SCI patients, lower the mortality and relieve the social burden. However, the treatment of SCI is still a clinical challenge worldwide. At present, studies on the treatment in SCI focus on the transplantation with Schwann's cells, neural stem cells, olfactory ensheathing cells, mesenchymal stem cells, $\operatorname{etc}^{27-31}$. Cell transplantation can promote the axonal regeneration and facilitate the functional recovery to a certain extent, but the renewable axons are insufficient. Previous experiments and clinical observation about spinal cord repair showed the key for spinal cord repair is to provide a channel for axon regeneration. There are some channels through which the axons in the partially injured spinal cord can grow. Following cell transplantation, stimulation or supply of neurotrophic factor, a number of axons grow through these channels, leading to good recovery of the partially injured spinal cord. However, the recovery of lumbosacral cord with transection injury is very difficult. Nowadays, experiments and clinical trials on SCI focus on the function reconstruction of pelvic organs with the horsetail and sacral nerves and results show the effectiveness to different extents ${ }^{32-33}$. However, few studies on direct neural transplantation or nerve anastomosis have been conducted to rebuild the movement of lower limbs below the level of injury ${ }^{34-37}$.

In 1963, Seddon et al. ${ }^{38}$ repaired the avulsed brachial plexus by autologous nerve transplantation, which was achieved by anastomosis between the $3^{\text {rd }}, 4^{\text {th }}$ intercostal nerve and musculocutaneous nerve. Ploncard ${ }^{39}$ confirmed the effectiveness of this strategy. According to previous findings, many researchers tried to achieve anastomosis between intercostal nerves and lumbar nerves innervating the quadriceps femoris to restore the function of quadriceps and rebuild the lower limbs movement following $\mathrm{SCI}^{18-25}$. Their results showed the regeneration of nerve fibers (intercostal nerves grew into lumbar nerves). Meanwhile, the action potentials of nerves and quadriceps femoris contraction were also noted in the electricophysiological examination. However, the paralyzed animals had poor initiative coordination and were unable to crawl/climb. We speculate that the intercostal nerves are mixed ones including motor and sensory nerve fibers and the amount of different nerve fibers is also different. Thereby, it is difficult to achieve the accurate anastomosis among identical nerve beams between intercostal nerves and spinal roots or other mixed nerves. Thus, the motor and sensory nerve fibers grow promiscuously. For this reason, although the nerve continuity was noted in the gross observation and histological examination, functional recovery was still limited and lower limb movements recovered poorly.

Our study aimed to rebuild the pathway of the nerve fibers in order to recover the motion of hindlimb in rats. After SCI, it is easy to result in the necrosis of the femoral nerve making anastomoses of nerves nonsense. Furthermore, thanks to the breeding time is longer, muscle strength deletion and bladder dysfunction lead to high mortality of animals. Respecting the above reasons, we designed the experiment which was rewiring nerves prior to the spinal cord injury.

Our results showed that anastomosis between normal ventral root above the level of injury and the nerve roots innervating target organs could achieve maximal potency, and recover the lower limb motor function. Because the ventral roots of spinal nerve belong to simple movement ones, the advantage is that the nerve pathways are built by anastomosis among motor nerve fiber bundles, which avoids crossover anastomosis among different nerve fiber bundles. Thus, the target organs are effectively innervated by motor nerves again and the lower limb motor function restores to a greater extent. This was achieved by the 
end-to-end anastomosis between the $\mathrm{L}_{1}$ and $\mathrm{L}_{3}$ ventral root which was the spinal nerve innervating the quadriceps femoris with the maximal potency with autologous nerve graft of cocygeal nerve. Six months postoperatively, the spinal cord was hemisected. Four weeks later, action potential of quadriceps femoris was recorded following stimulation of anastomotic nerve, and the evident contraction of quadriceps femoris also noted. Locomotion of the hindlimb partially restored and the rats could creep and climb. In addition, there was significant difference in the BBB score at one, three and seven days after SCI.

Anastomotic nerves was stained with H\&E and observed under light microscope and transmission electron microscope six months postoperatively. The regenerated nerve fibers were observed in the anastomotic site and arranged regularly, and mitochondria, a lot of synaptic vesicles and smooth endoplasmic reticulum were noted presenting similar ultramicrostructure to the normal nerves. After spinal cord hemisection, a paraspinal neural pathway was established for quadriceps femoris by endto-end anastomoses between spinal ventral root. Retrograde tracing was carried out by injecting TB into the femoral nerve in the affected side, and then filling and fixing were made four days later. According the design of the study, TB fluorescence stain should reach to the ventral corn of the L1 segment along the femoral nerve on the experimental side after establishing a paraspinal neural pathway of quadriceps femoris by end-to-end anastomoses between the spinal ventral root after SCI. The results showed the TB positive cells in the ventral corn of L1 segment in the affected side, which further confirmed morphologically that a paraspinal neural pathway had been established successfully and the theoretical basis was supplied to reestablish the lower limb movement function for patients with SCI.

\section{Conclusion}

End-to-end anastomosis between the spinal ventral roots using autologous nerve graft to reconstruct a paraspinal neural pathway for quadriceps femoris following SCI can promote the recovery of lower limb motor function and may have clinical implication in the treatment of human SCI.

\section{References}

1. Thulin CA, Carlsson CA. Regeneration of transected ventral roots submitted to monomolecular filter tubulation (millipore). An experimental study in cats. J Neurol Sci. 1969;8(3):485-505.

2. Sjöstrand J, Carlsson CA, Thulin CA. Regeneration of ventral roots. A histological study in cats. Acta Anat (Basel). 1969;74(4):532-46.
3. Richardson PM, McGuinness UM, Aguayo AJ. Axons from CNS neurons regenerate into PNS grafts. Nature. 1980;284(5753):264-5.

4. Richardson PM, Issa VM, Aguayo AJ. Regeneration of long spinal axons in the rat. J Neurocytol. 1984;13(1):165-82.

5. David S, Aguayo AJ. Axonal regeneration after crush injury of rat central nervous system fibres innervating peripheral nerve grafts. J Neurocytol. 1985;14(1):1-12.

6. Decherchi P, Gauthier P. Regrowth of acute and chronic injured spinal pathways within supra-lesional post-traumatic nerve grafts. Neuroscience. 2000;101(1):197-210.

7. Decherchi P, Gauthier P. In vitro pre-degenerated nerve autografts support CNS axonal regeneration. Brain Res. 1996;726(1-2):181-8.

8. Cullheim S, Carlstedt T, Risling M. Axon regeneration of spinal motoneurons following a lesion at the cord-ventral root interface. Spinal Cord. 1999;37(12):811-9.

9. Carlstedt T, Misra VP, Papadaki A, McRobbie D, Anand P. Spinal nerve root repair and reimplantation of avulsed ventral roots into the spinal cord after brachial plexus injury. J Neurosurg. 2000;93(2 Suppl):237-47.

10. Carlstedt T, Misra VP, Papadaki A, McRobbie D, Anand P. Return of spinal reflex after spinal cord surgery for brachial plexus avulsion injury. J Neurosurg. 2012;116(2):414-7.

11. Havton LA, Carlstedt T. Repair and rehabilitation of plexus and root avulsions in animal models and patients. Curr Opin Neurol. 2009;22(6):570-4.

12. Hallin RG, Carlstedt T, Nilsson-Remahl I, Risling M. Spinal cord implantation of avulsed ventral roots in primates; correlation between restored motor function and morphology. Exp Brain Res. 1999;124(3):304-10.

13. Htut M, Misra VP, Anand P, Birch R, Carlstedt T. Motor recovery and the breathing arm after brachial plexus surgical repairs, including re-implantation of avulsed spinal roots into the spinal cord. J Hand Surg Eur. 2007;32(2):170-8.

14. Carlstedt TP, Hallin RG, Hedström KG. Functional recovery in primates with brachial plexus injury after spinal cord implantation of avulsed ventral roots. J Neurol Neurosurg Psych. 1993;56(6):64954.

15. Carlstedt T, Aldskogius H, Hallin RG, Nilsson-Remahl I. Novel surgical strategies to correct neural deficits following experimental spinal nerve root lesions. Brain Res Bull. 1993;30(3-4):447-51.

16. Chang HY, Havton LA. Surgical implantation of avulsed lumbosacral ventral roots promotes restoration of bladder morphology in rats. Exp Neurol. 2008;214(1):117-24.

17. Hoang TX, Pikov V, Havton LA. Functional reinnervation of the rat lower urinary tract after cauda equina injury and repair. J Neurosci. 2006;26(34):8672-9.

18. Malik HG, Buhr AJ. Intercostal nerve transfer to lumber nerve roots. Part I: Development of an animal model and cadaver studies. Spine. 1979;4(5):410-5.

19. Dai KR, Yu CT, Wu RS, Zhang XF, Yuan JX, Sun YH. Intercostallumbar-spinal nerve anastomoses for cord transection. A preliminary investigation. J Reconstr Microsurg. 1985;1(3):223-6.

20. Tok S, Schmid UD, Ferbert A. Intercostolumbar spinal nerve anastomosis. An experimental study in dogs. Spine (Phila Pa 1976). 1991;16(4):463-6.

21. Vialle R, Lepeintre JF, Court C, Loureiro MC, Lacroix C, Tadié M. Anatomical feasibility of using the ninth, 10th, and 11th intercostal nerves for the treatment of neurological deficits after damage to the spinal cord. J Neurosurg Spine. 2006;4:225-32.

22. Vialle R, Harding I, Charosky S, Tadié M. The paraspinal splitting approach: a possible approach to perform multiple intercosto-lumbar neurotizations: an anatomic study. Spine. 2007;32(22):E631-4.

23. Vialle R, Lacroix C, Harding I, Loureiro MC, Tadié M. Motor 
and sensitive axonal regrowth after multiple intercosto-lumbar neurotizations in a sheep model. Spinal Cord. 2010;48(5):367-74.

24. Liu S, Damhieu P, Devanze P, Saïd G, Heard JM, Tadié M. Efficient reinnervation of hindlimb muscles by thoracic motor neurons after nerve cross-anastomosis in rats. J Neurosurg. 2003;99(5):879-85.

25. Vialle R, Lozeron P, Loureiro MC, Tadié M. Multiple lumbar roots neurotizations with the lower intercostal nerves. Preliminary clinical and electrophysiological results in a sheep model. J Surg Res. 2008;149(2):199-205.

26. Frankel HL, Coll JR, Charlifue SW, Whiteneck GG, Gardner BP, Jamous MA, Krishnan KR, Nuseibeh I, Savic G, Sett P. Long-term survival in spinal cord injury: a fifty year investigation. Spinal Cord. 1998;36(4):266-74.

27. Golden KL, Pearse DD, Blits B, Garg MS, Oudega M, Wood PM, Bunge MB. Transduced Schwann cells promote axon growth and myelination after spinal cord injury. Exp Neurol. 2007;207(2):20317.

28. Park IH, Zhao R, West JA, Yabuuchi A, Huo H, Ince TA, Lerou PH, Lensch MW, Daley GQ. Reprogramming of human somatic cells to pluripotency with defined factors. Nature. 2008;451(7175):141-6.

29. Eftekharpour E, Karimi-Abdolrezaee S, Wang J, El Beheiry $\mathrm{H}$, Morshead C, Fehlings MG. Myelination of congenitally dysmyelinated spinal cord axons by adult neural precursor cells results in formation of nodes of Ranvier and improved axonal conduction. J Neurosci. 2007;27(13):3416-28.

30. Lim JH, Piedrahita JA, Jackson L, Ghashghaei T, Olby NJ. Development of a model of sacrocaudal spinal cord injury in cloned Yucatan minipigs for cellular transplantation research. Cell Reprogram. 2010;12(6):689-97.

31. Wang D, Wen Y, Lan X. Experimental study on bone marrow mesenchymal stem cells seeded in chitosan-alginate scaffolds for repairing spinal cord injury. Chin J Repar Reconstruct Surg. 2010;24(2):190-6.

32. Xiao CG, Du MX, Dai C, Li B, Nitti VW, de Groat WC. An artificial somatic-central nervous system-autonomic reflex pathway for controllable micturition after spinal cord injury: preliminary results in 15 patients. J Urol. 2003;170(4):1237-41.

33. Hou CL, Zhong GB, Xie QP. Establishing an artificial reflex arc restore controlled micturition of flaccid bladder after spinal cord injury: a preliminary report. Chin J Microsurg. 2006;29(2):92-4

34. Zhang SC, Xu SG, Ma YH. Treatment of dated andincomplete spinal cord injury by loosing spinal dura mater and implanting autologous peripheral nerve. J Sec Milit Med Univ. 2004;25(7):803-4.

35. Tok S, Schmid UD, Ferbert A, Davenport T. Intercostolumbar spinal nerve anastomosis. An experimental study in dogs. Spine. 1991;16(4):463-6.

36. Zhao S, Beuerman RW, Kline DG. Neurotization of motor nerves innervating the lower extremity by utilizing the lower intercostal nerves. J Reconstr Microsurg. 1997;13(1):39-45.

37. Xu ZH, Tang TS, Fan SL. Electrophysiological change of the Spinal cord injured after nerve root transposition. Suzhou Uni J Med Sci. 2005;25(2):220-2

38. Seddon HJ. Nerve grafting. J Bone Joint Surg Br. 1963;45:447-61.

39. Ploncard P. A new approach to the intercosto-brachial anastomosis in the treatment of brachial plexus paralysis due to root avulsion. Later results. Acta Neurochir (Wien). 1982;61(4):281-90.

\section{Correspondence:}

Dr. Gui-bin Zhong

Department of Orthopaedic Surgery

Shanghai Jiao Tong University School of Medicine

Affiliated Renji Hospital, Shanghai 200127, China

Tel.: 86-013817066464

Fax: 86-021-58394262

doczhong@yeah.net

Received: January 18, 2012

Review: March 14, 2012

Accepted: April 16, 2012

Conflict of interest: none

Financial source: National Natural Science Foundation of China

${ }^{1}$ Research performed at Department of Orthopaedic Surgery, School of Medicine, Shanghai Jiao Tong University, Affiliated Renji Hospital, China. 